\title{
Adult-Onset Subacute Sclerosing Panencephalitis With Biphasic Course: Case Report
}

\author{
Erişkin Başlangıçlı Bifazik Seyirli Subakut Sklerozan Panensefalit: Olgu Sunumu
}

Canan Yücesan, Tuncay Çelik, Canan Togay Işıkay, Nermin Mutluer

Ankara Üniversitesi Tıp Fakültesi, Nöroloji Anabilim Dalı

We report a 27 years old man who was admitted to our hospital with progressive dementia that had begun two years ago. In his past medical history, his family reported a transient period of frequent falling and drop attacks of the head without any change of conscious, started when he was at age 18 and continued over three years; then he had a symptom-free period between the ages of 21-25 years. He had neither myoclonus nor periodic sharp and slow-wave discharges on electroencephalography (EEG) during the second phase of the disease that we saw him at age 27. Cerebrospinal fluid investigation disclosed high anti-measles IgG antibodies titer (1/640) and the patient was diagnosed with subacute sclerosing panencephalitis (SSPE). To our knowledge, this is the first case who had biphasic course without typical EEG findings of SSPE in the later phase of the disease.

Key Words: subacute sclerosing panencephalitis, electroencephalography

Biz 2 yıl önce başlayan ilerleyici demans tablosu ile hastanemize başvuran 27 yaşındaki bir erkek hastayı sunuyoruz. Hastanın ailesi, hastada 18 yaşında başlayıp 3 yıl devam eden, bilinç değişikliği olmaksızın yere düşme ve başta ani düşmeler şeklinde sık ataklar olduğunu, bu dönemi takiben 21-25 yaşları arasında hastanın tamamen normale döndüğünü bildirdi. Hastayı hastalığının ikinci fazında 27 yaşında iken gördüğümüzde, ne myoklonus ne de elektroensefalografisinde (EEG) periyodik keskin ve yavaş dalga deşarjları vardı. Hastanın beyin omurilik sıvısı incelemesinde yüksek titrede anti-kızamık antikorları (1/640) varlığı saptandı ve hastaya subakut sklerozan panensefalit tanısı konuldu (SSPE). Bizim bildiğimiz kadarı ile bu, bifazik seyreden, hastalığın daha ileri evresinde SSPE'nin tipik EEG bulguları olmayan ilk vaka bildirimidir.

Anahtar Kelimeler: subakut sklerozan panensefalit, elektroensefalografi

Subacute sclerosing panencephalitis (SSPE) is a persistent measles infection of the central nervous system that causes progressive inflammation and gliosis in brain leading to vegetative state followed by death. SSPE usually affects children and adolescents (1). Clinical features are characterized by progressive mental and motor deterioration, and myoclonus (2). Myoclonus can present as difficulty in gait, falling or dropping of the head. The electroencephalogram (EEG) usually reveals periodic complexes consisting of bilateral symmetric synchronous, high voltage bursts of delta waves (2). Brain magnetic resonance imaging (MRI) shows diffuse involvement of subcortical white matter that is usually seen in the occipital region initially. Cerebrospinal fluid (CSF) examination is generally normal except for high protein and IgG levels. The diagnosis is based on the raised titers of anti-measles antibodies in CSF (2). Although SSPE has usual clinical properties in the childhood, adult-onset SSPE is rare and may have atypical course (3-8).

\section{Case History}

A 27-year-old male was admitted to our hospital with progressive de- 
mentia, behavioral changes, urinary incontinence and gait disturbance that had begun two years ago. In his past medical history, his family reported a transient period of frequent falling and drop attacks of the head without any change of conscious that had started at 18-year-old age and continued over three years; because of the frequent falling attacks he had to quit his job and nursed by his parents. The family reported that although several combinations of antiepileptic agents had been tried for the falling attacks, it had not been seen any influence, and the falling attacks terminated spontaneously at age 21 . Then he returned to his job as a seller and even he joined the army as a soldier in that period. Moreover, his family described he had had measles infection at age 2 .

His physical examination was normal. Neurological examination revealed disorientation to time, place and people, spasticity and hyperactive deep tendon reflexes in all extremities, bilateral Babinski sign, spastic and mildly ataxic gait. Myoclonic jerks or drop attacks were not present in neurological examination. Mini-Mental State Examination score scale was 5/30. Neuro-psychological examination demonstrated psychomotor slowing, blunted affect, im- paired attention and concentration, verbal perseverations, dysnomia, dysgraphia, dyslexia, dyscalculia, clothing and constructional apraxia, right-left confusion, geographical disorientation and finger agnosia..

Routine blood chemistry studies revealed mildly increased levels of liver enzymes and serum lipids. Blood counts, sedimentation rate, thyroid function tests, and levels of serum B12 and folic acid were all normal. VDRL and anti-HIV antibodies were negative. Hepatobiliary ultrasonography showed mild hepatosteatosis. Hepatolenticular degeneration was excluded based on the normal levels of serum ceruloplasmine, urine copper and absence of Kayser-Fleischer ring. Although routine EEG showed only bilateral mild diffuse slow wave activity (a background activity of $7 \mathrm{~Hz}$ ) without any periodic sharp and slow-wave discharges at admission (Figure 1), bilateral periodic sharp and slow-wave discharges were seen on EEG performed when he was 20-year-old age (that was found in his past medical records) (figure 2). Brain MRI showed diffuse cerebral atrophy and increased intensity in bilateral periventricular and subcortical white matter on T2 weighted images. Cerebrospinal fluid (CSF) examination showed high pro- tein level (73 $\mathrm{mg} / \mathrm{dl})$ and IgG index (1.13), and oligoclonal bands. Furthermore, anti-measles IgG antibodies titer was high (1/640) in CSF. The patient was diagnosed with SSPE based on the clinical and laboratory findings, and treated with interferon beta $1 \mathrm{a} 44 \mathrm{mcg}$ subcutaneous injections three times in a week and oral inosiplex $100 \mathrm{mg} / \mathrm{kg} /$ day but did not seen any clinical response over three months.

\section{Discussion}

We thought the first signs of SSPE in our patient had begun at 18 years old age based on his past medical history and EEG findings at age 20, and he had spontaneous remission at age 21. Then he had a symptom-free period between the ages of 21-25 years. It has been known that spontaneous remission is possible in childhood-onset SSPE cases, however, it is rare in adult-onset SSPE cases. Although around 100 cases of adult onset SSPE cases have been published to date, only a few of them have been reported having spontaneous remission in the disease course $(3,5,7,8)$.

In SSPE cases, memory loss and personality changes usually occur with myoclonus and focal neuro-

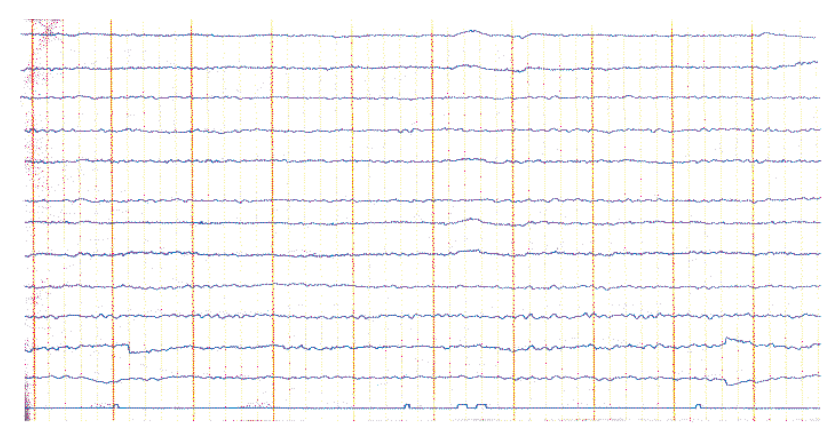

Figure 1. Electroencephalogram showing bilateral diffuse slow wave activity without any periodic sharp and slow-wave discharges at admission in the second phase of the disease.

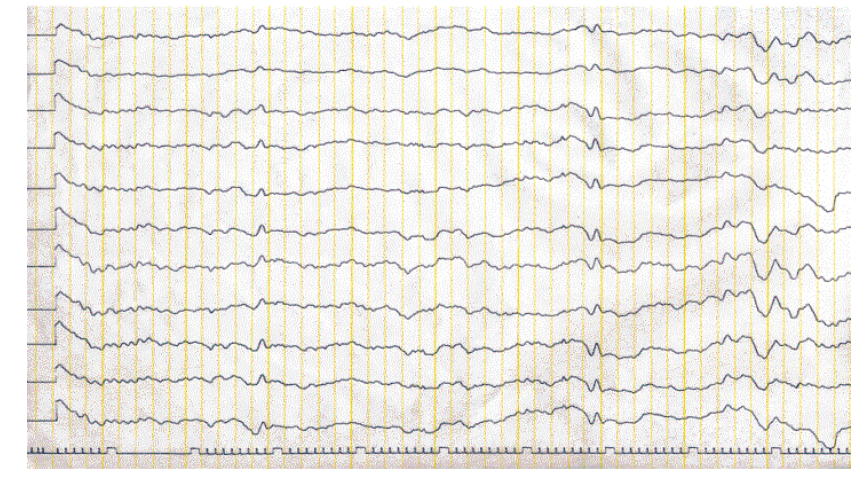

Figure 2. Electroencephalogram showing bilateral periodic sharp and slow-wave discharges in the first phase of the disease. 
logical deficits. Our patient's past medical history revealed myoclonic jerks in the first phase of the disease, however he had not myoclonus although he had memory loss and personality changes during the second phase of the disease that we saw him. It has been known that EEG may be normal or show only moderate non-specific generalized slowing in the early phase of the disease $(2,4)$. Even though our case had had typ-

\section{REFERENCES}

1. Onal AE, Gürses C, Direşkeneli GS, Yılmaz G, Demirbilek V, Yentur SP, Özel S, Yapıcı Z, Tümerdem Y, Gökyigit A. Subacute sclerosing panencephalitis surveillance study in İstanbul. Brain Dev. 2006;28:183-189

2. Garg RK. Subacute sclerosing panencephalitis. Postgrad Med J 2002;78:63-70.

3. Singer C, Lang AE, Suchowersky O. Adult-onset subacute sclerosing panencephalitis: case reports and review of the literature. Movement ical bilateral periodic sharp and slow-wave discharges on EEG that was performed at age 20, in the first phase of the disease, his EEG showed no typical periodic sharp and slow-wave discharges in spite of progressive deterioration of the clinical picture in the second phase of the disease that we saw him. To our knowledge, this is the first case who had biphasic course without typical EEG findings of SSPE in the later stage of the dis-

Disorders 1997; 12:342-353.

4. Frings M, Blaeser I, Kastrup O. Adultonset subacute sclerosing panencephalitis presenting as a degenerative dementia syndrome. J Neurol 2002;249: 942-943.

5. Callebaut DP, Cras P, Martın JJ. Prolonged and atypical course in some cases of subacute sclerosing panencephalitis. Acta Neurol Belg 1997;97:39-44.

6. Prashanth LK, Taly AB, Ravi V, Sinha S, Arunodaya GR. Adult onset subacute sclerosing panencephalitis: ease. Based on the case, we suggest that SSPE should be suspected in the cases with early-onset progressive dementia even they do not have myoclonic jerks in the neurological examination and typical periodic sharp and slow-wave discharges in EEG, and CSF examination should be done in that kind of patients.

clinical profile of 39 patients from a tertiary care centre. J Neurol Neurosurg Psychiatry 2006;77:630-633.

7. Ortega-Aznar A, Romero-Vidal FJ, Castellví J, Ferrer JM, Codina A. Adult-onset subacute sclerosing panencephalitis: clinico-pathological findings in 2 new cases. Clin Neuropathol 2003; 22(3):110-118.

8. Santoshkumar B, Radhakrishnan . Substantial spontaneous long-term remission in subacute sclerosing panencephalitis (SSPE). J Neurol Sci 1998;154: 83-88. 